\title{
Hubungan Durasi dan Intensitas Penggunaan Gadget dengan Perkembangan Personal Sosial Anak Usia Prasekolah (3-5 Tahun) di TK Cendikia Desa Lingsar Tahun 2019
}

\author{
Khairul Putriana ${ }^{1}$, Eka Adithia Pratiwi ${ }^{1}$, Indah Wasliah ${ }^{2}$ \\ Email: indahwasliah80@gmail.com \\ ${ }^{1}$ Prodi S.1 Ilmu Keperawatan Stikes Yarsi Mataram \\ ${ }^{2}$ Prodi Ners Stikes Yarsi Mataram
}

\begin{abstract}
ABSTRAK
Sekitar 5 hingga 10\% anak diperkirakan mengalami keterlambatan perkembangan. Data angka kejadian keterlambatan perkembangan umum belum diketahui dengan pasti, namun diperkirakan sekitar 1-3\% anak di bawah usia 5 tahun mengalami keterlambatan perkembangan umum. Pengenalan atau penggunaan gadget sejak dini kepada anak akan berdampak terhadap perkembangan anak. Tujuan penelitian ini adalah untuk mengetahui hubungan durasi dan intensitas penggunaan gadget dengan perkembangan mpersonal sosial anak usia 3-5 tahun di TK Cendikia Lingsar. Desain penelitian yang digunakan pada penelitian ini adalah cross sectional, dan menggunakan DDST sebagai instrumen. Pengambilan sampel dalam penelitian ini menggunakan teknik total sampling yaitu teknik pengambilan sampel dengan jumlah sample 34 orang. Hasil penelitian ini menunjukkan bahwa anak yang bermain gadget dengan intensitas penggunaan gadget $>3 \mathrm{kali} / \mathrm{hari}$ yaitu sebanyak 15 orang $(43,1 \%)$ dengan durasi sedang yaitu 40-60 menit yaitu sebanyak 15 orang $(44,1 \%)$. Hasil uji korelasi Chi-Square didapatkan p-value menunjukkan bahwa untuk intensitas penggunaan gadget $(\mathrm{p}=0,032 \alpha=0,005)$ dan untuk durasi penggunaan gadget ( $p=0,004 \alpha=0,005)$ maka dapat disimpulkan bahwa ada hubungan antara durasi dan intensitas penggunaan gadget dengan perkembangan personal sosial anak usia 3-5 tahun. Berdasarkan hasil penelitian, disarankan bagi orang tua untuk lebih selektif lagi dalam memberikan mainan kepada anak dan perlu adanya pengawasan serta ketegasan dalam memberikan batasan kepada anak dalam bermain gadget.
\end{abstract}

Kata Kunci: Gadget, Perkembangan Personal Sosial, Anak Usia 3-5 tahun.

\begin{abstract}
There were 5 to $10 \%$ of children estimated to experience developmental delays. Data on the incidence of general developmental delays was not known with certainty, but it is estimated that around $1-3 \%$ of toddlers experience general developmental delays. The use of gadgets early on children will have an impact on children's development. The purpose of this study is to determine the correlation of duration and intensity of gadget use with social personal development of toddlers in TK Cendikia Lingsar. The research design used in this study was cross sectional, and DDST as an instrument. Sampling in this study used was total sampling technique that numbers of samples used were 34 people. The results of this study indicate that children who play gadgets with intensity of gadget usage $>3$ times / day as many as 15 people $(43.1 \%)$ with a moderate duration of $40-60$ minutes, namely as many as 15 people $(44.1 \%)$. ChiSquare correlation test results obtained $\mathrm{p}$-value shows that for the intensity of gadget use ( $\mathrm{p}=$ $0.032 \alpha=0.005)$ and for the duration of gadget use $(p=0.004 \alpha=0.005)$, it can be concluded that there is a correlation between the duration and intensity of gadget usage with the personal social development of children aged 3-5 years. Based on the results of the study, it is recommended for parents to be more selective in giving toys to children and the need for supervision and firmness in providing limits to children in playing gadgets.
\end{abstract}

Keywords: Gadgets, Social Personal Development, 3-5 Year Old Children. 


\section{A. LATAR BELAKANG}

Pertumbuhan dan perkembangan pada masa prasekolah merupakan tahapan dasar yang sangat berpengaruh dan menjadi landasan untuk perkembangan selanjutnya [1]. Masa ini berlangsung singkat sehingga disebut masa kritis atau critical period dan masa keemasan atau golden gold. Gangguan tumbuh kembang sekecil apapun yang terjadi pada anak usia di usia prasekolah ini, apabila tidak terdeteksi dan di intervensi sedini mungkin akan mengurangi kwalitas sumber daya manusia di masa akan datang.

Gangguan perkembangan pada anak merupakan masalah yang banyak dijumpai di masyarakat, sehingga sangat penting apabila semua komponen yang terlibat dalam proses perkembangan anak, yaitu orang tua, guru, dan masyarakat dapat bekerja sama dalam melakukan pemantauan sejak dini. Beberapa ahli perkembangan menyatakan bahwa, anak yang tidak mengalmi pengasuhan yang hangat dan lembut, selama tahun pertama atau lebih kehidupannya, maka perkembangannya tidak akan optimal [2].

Sekitar 5 hingga $10 \%$ anak diperkirakan mengalami keterlambatan perkembangan. Data angka kejadian keterlambatan perkembangan umum belum diketahui dengan pasti, namun diperkirakan sekitar 1-3\% anak di bawah usia 5 tahun mengalami keterlambatan perkembangan umum [3]. Salah satu masalah perkembangan anak yang perlu di perhatikan adalah tentang masalah perkembangan personal sosial. Masalah perkembangan personal sosial pada pola asuh anak pra sekolah di antaranya adalah anak tidak mempunyai kemampuan dalam bersosialisasi dan kemandirian mencapai angka $56,61 \%$ pada anak usia pra sekolah [4]. Masalah perkembangan personal sosial pada anak pra sekolah yang kurang, akan menyebabkan anak tidak memiliki kesiapan dalam melangkah kejenjang yang lebih tinggi yaitu tingkat Sekolah Dasar (SD). Anak dengan masalah perkembangan personal sosial akan memiliki prestasi belajar yang kurang, suka marah, suka berkelahi, suka menantang, berubut dan menangis.

Menurut Susanto [5] banyak faktor yang mempengaruhi perkembangan anak seperti keturunan, lingkungan, kematangan, pembentukan, minat dan bakat, dan kebebasan. Menurut hasil penelitian Novitasari dan Khotimah [6] salah satu faktor yang mempengaruhi perkembangan personal sosial anak yaitu kebiasaan dalam bermain gadget.

Gadget adalah sebuah benda (benda atau barang elektronik) teknologi kecil yang memiliki fungsi khusus, tetapi sering di asosiasikan sebagai sebuah inovasi atau barang baru. Era globalisasi sekarang yang serba modern dan canggih, fungsi gadget (handphone / tablet) tidak hanya difungsikan untuk berkomunikasi saja, tetapi lebih cenderung kepada untuk bermain game, multimedia (mendengar musik dan menonton video), serta layanan internet (sosial media). Perkembangan gadget yang dulunya cenderung hanya dimiliki oleh orang kaya karena harganya yang relatif mahal saat itu, kini mulai dapat dimiliki oleh siapa saja karena harga gadget yang sudah mulai beragam dari ratusan ribu sampai jutaan. Sehingga tidak heran di era globalisasi ini, anak SD bahkkan anak-anak usia pra sekolah sudah ada yang memakai gadget (handphone/tablet) dan mengoperasikannya [7]. Pengenalan atau penggunaan gadget sejak dini kepada anak tentu akan berdampak terhadap perkembangan anak. Dampak negatif penggunaan gadget pada anak antara lain penurunan konsentrasi, menghambat perkembangan motorik, malas menulis dan membaca, penurunan kemampuan bersosialisasi, kecanduan, gangguan kesehatan, perkembangan kognitif terhambat, dan menghambat kemampuan berbahasa [8].

Penelitian di Indonesia mendeteksi adanya gangguan perkembangan anak pada usia prasekolah mencapai $12,8 \%-28,5 \%$ dari seluruh populasi anak usia prasekolah [9]. Badan Koordinasi Keluarga Berencana Nasional 
menyebutkan bahwa apabila anak balita tidak dibina dan diasuh secara baik, maka anak tersebut akan mengalamai gangguan perkembangan emosi, sosial, mental, intelektual dan moral yang nantinya dapat pempengaruhi kemandirian sikap dan perilakunya dimasa yang akan datang.

Menurut penelitian Sari dan Mitsalia [10] yang berjudul Pengaruh Penggunaan Gadget terhadap Personal Sosial Anak Usia Pra Seklolah di TKIT Al Mukmin membuat simpulan terhadap penelitian yang telah dilakukannya, bahwa ada pengaruh yang bermakna atau signifikan antara penggunaan gadget dengan personal sosial anak usia pra sekolah di TK Al Mukmin.

Berdasarkan studi pendahuluan yang dilakukan penulis di TK Cendikia, terdapat jumlah anak didik yaitu 39 anak, yang terdiri dari usia 5 tahun sebanyak 17 anak, usia 4 tahun sebanyak 12 anak dan usia 3 tahun sebanyak 10 anak. Dari survey yang dilakukan penulis pada tanggal 24 September 2018 menggunakan tes DDST terhadap 5 orang anak, 3 diantaranya mengalami suspect keterlambatan perkembangan personal sosial yang meliputi; anak belum mampu berpakaian secara mandiri, menggosok gigi dan mengambil makanan masih dengan bantuan. Saat dilakukan wawancara, orang tua mengatakan durasi bermain gadget pada anak mereka berbeda-beda antara 6-8 jam perhari dan orang tua beranggapan bahwa permainan dan fitur-fitur di dalam gadget membuat anak lebih anteng dan mengurangi perilaku rewel sehingga orang tua bisa menyelesaikan aktivitas sehari-sehari dengan mudah.

\section{B. METODE PENELITIAN}

Jenis penelitian yang digunakan adalah korelasional, penelitian ini akan menguji hubungan penggunaan gadget dengan perkembangan personal sosial anak usia prasekolah (3-5 tahun) di TK Cendikia desa Lingsar. Adapun desain penelitian yang digunakan adalah cross sectional. Penelitian dilakukan pada bulan April tahun 2019, di TK Cendikia dusun Onor, desa Lingsar, kecamatan Lingsar, kabupaten Lombok Barat, Nusa Tenggara Barat.

Populasi dalam penelitian ini adalah seluruh anak-anak usia 3-5 tahun sebanyak 34 anak. Pengambilan sampel dalam penelitian ini menggunakan teknik total sampling, dengan kriteria responden yang digunakan oleh peneliti adalah :

\section{Kriteria inklusi}

a. Orang tua dan anak yang bersedia jadi responden

b. Orang tua yang memiliki anak dengan usia 3-5 tahun

c. Anak yang bermain gadget setiap hari

Kriteria eksklusi :

a. Anak dengan gangguan perkembangan

b. Anak dalam keadaan sakit dan rewel saat dilakukan tes DDST

Pertimbangan etika penelitian, maka responden dilindungi dengan memperhatikan aspek-aspek: informed concent, privacy, anonymity, confidentially, protection from discomfort dan justice. Alat yang digunakan dalam penelitian ini adalah lembar observasi dan lembar DDST. Lembar Observasi bertujuan untuk mengisi data dari orang tua/pengasuh mengenai intensitas dan durasi penggunaan gadget pada anak sedangkan lembar DDST untuk mengetahui tahap perkembangan yang telah dicapai oleh anak. Untuk lembar DDST tidak perlu dilakukan uji validitas dan reabilitas karena lembar DDST tersebut sudah baku.

Data yang telah dikumpulkan sebelum dianalisis, terlebih dahulu dilakukan beberapa proses diantaranya Editing, Coding, Entry data, Cleaning. Data dipastikan telah benar maka dilanjutkan ke tahap analisis dengan menggunakan komputer. Analisis yang dilakukan adalah analisis univariat dan bivariat.

C. HASIL DAN PEMBAHASAN

1. Analisa Univariat

a. Distribusi Frekuensi Responden Berdasarkan Usia 
Tabel 1. Distribusi Frekuensi Responden Berdasarkan Usia di TK Cendikia Lingsar Tahun 2019

\begin{tabular}{|c|c|c|}
\hline Usia Anak & Jumlah & Persentase (\%) \\
\hline 3 Tahun & 8 & 23,5 \\
\hline 4 Tahun & 10 & 29,4 \\
\hline 5 Tahun & 16 & 47,1 \\
\hline Jumlah & 34 & 100.0 \\
\hline
\end{tabular}

Berdasarkan tabel diatas, dapat diketahui bahwa anak yang berusia 3 tahun yaitu sebanyak 8 responden (23,5\%), sedangkan anak yang berusia 4 tahun sebanyak 10 responden $(29,4 \%)$ dan anak yang berusia 5 tahun sebanyak 16 responden $(47,1 \%)$. Jumlah anak terbanyak yaitu usia 5 tahun sebanyak 16 responden $(47,1 \%)$, dan jumlah anak paling sedikit yaitu anak usia 3 tahun sebanyak 8 responden $(23,5 \%)$.

\section{b. Distribusi Frekuensi Responden \\ Berdasarkan Jenis Kelamin}

Tabel 2. Distribusi Frekuensi Responden

Berdasarkan Jenis Kelamin di TK Cendikia Lingsar

Tahun 2019

\begin{tabular}{|c|c|c|}
\hline Jemis Kelamin Anak & Jumlah & Persentase (\%) \\
\hline Laki-laki & 13 & 38,2 \\
\hline Perempuan & 21 & 61,8 \\
\hline Jumlah & 34 & 100.0 \\
\hline
\end{tabular}

Berdasarkan tabel diatas, dapat diketahui bahwa anak yang berjenis kelamin perempuan lebih banyak yaitu 21 responden $(61,8 \%)$. Anak berjenis kelamin laki-laki lebih sedikit yaitu sebanyak responden 13 responden $(38,2 \%)$.

\section{c. Distribusi Frekuensi Responden \\ Penggunaan Gadget}

Tabel 3. Distribusi Frekuensi Responden Berdasarkan Intensitas Penggunaan Gadget Pada Anak Usia 3-5 Tahun di TK Cendikia Lingsar Tahun 2019

\begin{tabular}{|c|c|c|}
\hline $\begin{array}{c}\text { Intensitas Penggunaan } \\
\text { Gadget }\end{array}$ & Jumlah & $\begin{array}{c}\text { Persentase } \\
(\%)\end{array}$ \\
\hline Maksimal 1-2kali/hari & 8 & 23.5 \\
\hline 2-3kali/hari & 11 & 32.4 \\
\hline$>$ 3 kali/hari & 15 & 43.1 \\
\hline Jumlah & 34 & 100.0 \\
\hline
\end{tabular}

Berdasarkan tabel 3, dapat diketahui bahwa anak yang menggunakan gadget dengan intensitas penggunaan gadget $>3 \mathrm{kali} / \mathrm{hari}$ yaitu sebanyak 15 responden $(43,1 \%)$, sedangkan anak yang bermain gadget dengan intensitas penggunaan gadget 2-3 kali/hari sebanyak 11 responden $(32,4 \%)$ dan anak yang bermain gadget dengan intensitas penggunaan gadget maksimal 1-2 kali/hari sebanyak 8 responden $(23.5 \%)$. Jumlah penggunaan terbanyak dengan intensitas tinggi yaitu $>3$ kali/hari sebanyak 15 responden dan jumlah penggunaan paling sedikit dengan intensitas rendah yaitu maksimal 1-2 kali/hari.

Tabel 4. Distribusi Frekuensi Responden Berdasarkan Durasi Penggunaan Gadget Pada Anak Usia 3-5 Tahun di TK Cendikia Lingsar Tahun 2019

\begin{tabular}{|c|c|c|}
\hline $\begin{array}{c}\text { Durasi Penggunaan } \\
\text { Gadget }\end{array}$ & Jumlah & $\begin{array}{c}\text { Persentase } \\
(\%)\end{array}$ \\
\hline Rendah (5-30 menit) & 11 & 32.4 \\
\hline Sedang (40-60 menit) & 15 & 44.1 \\
\hline Tinggi (75-120 menit) & 8 & 23.5 \\
\hline Jumlah & 34 & 100.0 \\
\hline
\end{tabular}

Berdasarkan tabel diatas, dapat diketahui bahwa anak yang bermain gadget dengan durasi tinggi yaitu 75-120 menit yaitu sebanyak 8 responden $(23,5 \%)$, sedangkan anak yang bermain gadget dengan durasi sedang yaitu 40-60 menit yaitu sebanyak 15 responden $(44,1 \%)$, dan anak yang bermain gadget dengan durasi rendah 5-30 menit sebanyak 11 responden $(32,4 \%)$. Jumlah anak yang menggunakan gadget dengan tingkat durasi paling banyak yaitu sedang selama 40-60 menit dan penggunaan gadget dengan tingkat durasi paling sedikit yaitu tinggi selama 75-120 menit.

\section{d. Distribusi Frekuensi Responden Berdasarkan Perkembangan Personal Sosial Anak Usia 3-5 Tahun}

Distribusi frekuensi responden perkembangan personal sosial anak usia 3-5 tahun di TK Cendikia Tahun 2019 dapat dilihat pada tabel 5.

Berdasarkan tabel 5, dapat diketahui bahwa responden yang mengalami suspect adalah sebanyak 4 responden $(11,8 \%)$ dan responden 
yang masuk katagori normal sebanyak 30 responden $(88,2 \%)$

Tabel 5. Distribusi Frekuensi Responden

Perkembangan Personal Sosial Anak Usia 3-5

Tahun di TK Cendikia Lingsar Tahun 2019

\begin{tabular}{|c|c|c|}
\hline $\begin{array}{c}\text { Perkembangan Personal } \\
\text { Sosial Anak Usia 3-5 } \\
\text { Tahun }\end{array}$ & Jumlah & Persentase \\
\hline Suspect & 4 & 11,8 \\
\hline Normal & 30 & 88,2 \\
\hline Total & 34 & 100.0 \\
\hline
\end{tabular}

\section{Analisa Bivariat}

\section{a. Analisis hubungan intensitas penggunaan gadget dengan perkembangan personal sosial anak usia 3-5 tahun}

Analisis hubungan intensitas penggunaan gadget dengan perkembangan personal sosial anak usia 3-5 tahun di TK Cendikia desa Lingsar tahun 2019 dapat dilihat pada 6.

Tabel 6. Analisis Hubungan Durasi Penggunaan Gadget dengan Perkembangan Personal Sosial Anak Usia 3-5 Tahun di TK Cendikia Desa Lingsar Tahun 2019

\begin{tabular}{|c|c|c|c|c|c|c|c|}
\hline $\begin{array}{c}\text { Penggu } \\
\text { naan } \\
\text { Gadget }\end{array}$ & $\begin{array}{c}\text { Perkemba } \\
\text { ngan } \\
\text { Normal }\end{array}$ & $\begin{array}{c}\text { Perkemba } \\
\text { ngan } \\
\text { Suspect }\end{array}$ & \multicolumn{2}{|c|}{ Total } & \multirow{2}{*}{$\begin{array}{c}\text { P } \\
\text { value }\end{array}$} \\
\cline { 2 - 6 } & $\mathrm{N}$ & $\%$ & $\mathrm{~N}$ & $\%$ & $\mathrm{~N}$ & $\%$ & \\
\hline \multicolumn{7}{|c|}{ Durasi Penggunaan Gadget } \\
\hline Rendah & 10 & 29.4 & 0 & 0.0 & 10 & 29.4 & \multirow{2}{*}{} \\
\hline Sedang & 15 & 44.1 & 1 & 5.2 & 16 & 47.1 & 0.032 \\
\hline Tinggi & 5 & 14.7 & 3 & 37.5 & 8 & 23.5 & \\
\hline Jumlah & 30 & 88,2 & 4 & 11,8 & 34 & 100 & \\
\hline
\end{tabular}

Berdasarkan tabel diatas, dapat diketahui bahwa responden yang mengalami suspect perkembangan personal sosial sebanyak 3 responden $(37,5 \%)$ anak dengan penggunaan durasi tinggi dan 1 responden $(5,2 \%)$ perkembangan suspect dengan penggunaan gadget durasi sedang. Anak dengan perkembangan personal sosial normal paling banyak menggunakan gadget sedang yaitu sebanyak 15 responden $(44,1 \%)$ anak dan paling sedikit penggunaan durasi tinggi sebanyak 5 responden $(14,7 \%)$.

Hasil uji Chi Square menunjukkan bahwa untuk intensitas penggunaan gadget $(\mathrm{p}=0,041<$ $\alpha=0,05)$ maka dapat disimpulkan bahwa ada hubungan antara intensitas penggunaan gadget dengan perkembangan personal sosial anak usia 3-5 tahun.

\section{b. Hasil analisis hubungan durasi penggunaan gadget dengan perkembangan personal sosial anak usia 3-5 tahun}

Analisis hubungan intensitas penggunaan gadget dengan perkembangan personal sosial anak usia 3-5 tahun di TK Cendikia desa Lingsar tahun 2019 dapat dilihat 7.

Tabel 7. Analisis Hubungan Durasi Penggunaan Gadget dengan Perkembangan Personal Sosial Anak Usia 3-5 Tahun di TK Cendikia Desa Lingsar Tahun 2019

\begin{tabular}{|l|c|c|c|c|c|c|c|c|}
\hline \multirow{7}{*}{$\begin{array}{c}\text { Penggu } \\
\text { naan } \\
\text { Gadget }\end{array}$} & $\begin{array}{c}\text { Perkemban } \\
\text { gan } \\
\text { Normal }\end{array}$ & \multicolumn{2}{|c|}{$\begin{array}{c}\text { Perkemba } \\
\text { ngan } \\
\text { Suspect }\end{array}$} & \multicolumn{2}{|c|}{ Total } & \multirow{2}{*}{$\begin{array}{c}\text { P } \\
\text { value }\end{array}$} \\
\cline { 2 - 7 } & $\mathrm{N}$ & $\%$ & $\mathrm{~N}$ & $\%$ & $\mathrm{~N}$ & $\%$ & \\
\hline \multicolumn{7}{|c|}{ Durasi Penggunaan Gadget } \\
\hline $\begin{array}{l}\text { Max 1- } \\
2 \mathrm{x} / \text { hari }\end{array}$ & 8 & 23.5 & 0 & 0.0 & 8 & 23.5 & \\
\hline $\begin{array}{l}2-3 \mathrm{x} \\
\text { /hari }\end{array}$ & 11 & 32.35 & 0 & 0.0 & 11 & 32.5 & \multirow{2}{*}{0.041} \\
\cline { 1 - 6 } $\begin{array}{l}>3 \text { kali } \\
\text { /hari }\end{array}$ & 11 & 32.35 & 4 & 11.8 & 15 & 14.5 & \\
\cline { 1 - 3 } & 30 & 88,2 & 4 & 11,8 & 34 & 100 & \\
\hline
\end{tabular}

Berdasarkan tabel diatas, dapat diketahui anak yang mengalami perkembangan personal sosial suspect sebanyak 4 (11,8\%) anak dengan intensitas penggunaan $>3 \mathrm{kali} / \mathrm{hari}$. Anak dengan perkembangan personal sosial normal sebanyak $11(32.35 \%)$ anak dengan intensitas penggunaan gadget 2-3 kali/hari dan 11 (32,35\%) anak dengan penggunaan intensitas penggunaan gadget. Penggunaan gadget max 1-2 kali/hari sebanyak 8 anak.

Hasil uji Chi Square menunjukkan bahwa durasi penggunaan gadget $(\mathrm{p}=0,032 \alpha=0,05)$ maka dapat disimpulkan bahwa ada hubungan 
antara bermain gadget dengan perkembangan personal sosial anak usia 3-5 tahun.

\section{Penggunaan Gadget PadaAnak}

Dari hasil penelitian yang dilakukan di TK Cendikia Lingsar, didapatkan bahwa anak yang bermain gadget dengan intensitas penggunaan gadget $>3 \mathrm{kali} /$ hari yaitu sebanyak 11 responden $(32,35 \%)$, sedangkan anak yang bermain gadget dengan intensitas penggunaan gadget 2-3 kali/hari sebanyak 11 responden $(32,35 \%)$ dan anak yang bermain gadget dengan intensitas penggunaan gadget maksimal 1-2 kali/hari sebanyak 8 responden $(23.5 \%)$.

Gadget merupakan sebuah inovasi dari teknologi terbaru dengan kemampuan yang lebih baik dan fitur terbaru yang memiliki tujuan maupun fungsi lebih praktis dan juga lebih berguna. Gadget adalah sebuah istilah yang berasal dari bahasa Inggris, yang artinya perangkat elektronik kecil yang memiliki fungsi khusus. Contoh-contoh dari gadget di antaranya adalah telepon pintar (smartphone) seperti iphone dan blackberry, serta notebook (perpaduan antara komputer portabel seperti notebook dan internet) [11].

Keberadaan gadget di era yang semakin berkembang ini memberikan dampak positif dan dampak negatif bagi penggunanya. Menurut Hardianto salah satu dampak negatif dari penggunaan gadget pada anak yang tidak dibatasi adalah penurunan dalam kemampuan bersosialisasi, (misalnya anak kurang bermain dengan teman dilingkungan sekitarnya, tidak memperdulikan keadaan sekelilingnya). Kondisi ini akan berdampak buruk apabila responden tua secara terus-menerus memberikan gadget pada anak.

Menurut penelitian yang dilakukan Rideout didapatkan hasil bahwa terdapat anak usia 2-4 tahun telah menghabiskan waktu di depan layar selama 1 jam 58 menit perharinya dan anak usia 5-8 tahun menghabiskan waktu di depan layar selama 2 jam 21 menit setiap harinya. Hal ini bertentangan dengan pendapat Starburger yang menyatakan anak hanya boleh berada di depan layar $\leq 1$ jam setiap harinya. Menurut Ferliana
[12], anak usia dibawah 5 tahun, boleh-boleh saja diberi gadget. Tapi harus diperhatikan durasi pemakaiannya, misalnya, boleh bermain tapi hanya setengah jam dan hanya pada saat senggang, kenalkan gadget seminggu sekali, misalnya hari sabtu atau minggu.

Menurut Sari dan Mitsalia [10], pemakaian gadget dikategorikan dengan intensitas tinggi jika menggunakan gadget dengan durasi lebih dari 120 menit/hari dan dalam sekali pemakaiannya berkisar $>75$ menit. Selain itu, dalam sehari bisa berkali-kali (lebih dari 3 kali pemakaian) pemakaian gadget dengan durasi 3075 menit akan menimbulkan kecanduan dalam pemakaian gadget. Selanjutnya, pemakaian gadget dalam intensitas sedang jika menggunakan gadget dengan durasi lebih dari 40-60 menit/hari dan intensitas penggunaan maksimal 2 kali pemakaian.

Hasil penelitian ini menunjukkan bahwa sebagian besar anak usia 3-5 tahun di TK Cendikia Lingsar, memiliki kebiasaan bermain gadget dengan rentang waktu 40-60 menit dengan intensitas $3 \mathrm{kali} / \mathrm{hari}$. Menurut penelitian sebelumnya, yang dilakukan oleh Salsabila mengatakan bahwa lama atau durasi penggunaan gadget oleh anak-anak dapat memberikan pengaruh terhadap perkembangannya. Hal tersebut di dukung oleh hasil penelitian Novitasari dan Khotimah [6] bahwa pengenalan gadget terlalu dini pada anak dapat mempengaruhi perkembangan personal sosial anak.

Pada bagian hasil penelitian ini pula, dapat dilihat bahwa terdapat selisih jumlah yang cukup banyak antara anak yang sering menggunakan gadget dengan durasi dan intensitas yang normal dengan durasi dan intensitas yang tinggi. Hal ini dikarenakan bentuk pengalihan ataupun kurangnya waktu responden tua dalam hal menemani anak untuk bermain dan responden tua beranggapan bahwa fitur-fitur yang ada di gadget membuat anak menjadi lebih anteng sehingga responden tua dapat melakukan aktivitasnya dengan mudah. 


\section{Perkembangan Personal Sosial pada Anak Usia 3-5 Tahun}

Hasil penelitian menunjukkan ada beberapa anak usia 3-5 tahun di TK Cendikia Lingsar mengalami suspect perkembangan personal sosial. Responden yang mengalami suspect $(\geq 2$ caution/peringatan dan/ $\geq 1$ keterlambatan) adalah sebanyak 4 responden $(11,4 \%)$. Perkembangan personal sosial yang gagal dilakukan anak yaitu seperti mengambil makanan dimana anak tersebut lebih sering disiapkan makanannya oleh responden tua. Perkembangan sosial yang gagal dilakukan juga seperti menggosok gigi tanpa bantuan, masih diarahkan untuk menggosok gigi lebih dalam dan lebih lama.

Perkembangan personal sosial anak usia prasekolah adalah suatu proses perubahan yang terus menerus pada anak usia 3-5 tahun dimana anak belajar untuk mandiri, berinteraksi dan berprilaku dengan lingkungan dan responden lain (teman sebaya). Pada tahap perkembangan personal sosial ini, anak mulai menguasai keterampilan fisik, bahasa dan anak juga memiliki rasa percaya diri untuk mengeksplorasi kemandiriannya.

Menurut hasil penelitian yang dilakukan oleh Tria Puspita Sari dan Ami Asma Mitsalia [10] menyatakan bahwa, disamping memiliki dampak positif, anak yang suka bermain gadget, juga memiliki dampak negatif terhadap perkembangan personal sosial anak, seperti anak cenderung pendiam, anak lebih senang memainkan gadgetnya daripada bermain dengan temannya, anak terkadang menirukan adegan kekerasan yang ada di game, anak bersikap acuh bila sudah di depan gadgetnya, dan lain-lain. Hal ini juga sependapat dengan penelitian yang dilakukan oleh Puji Asmaul Chusna tahun 2016 yang menyatakan bahwa, kini kehidupan sosial anak-anak lebih terpengaruh oleh teknologi. Lebih sering anak usia dini berinteraksi dengan gadget dan juga dunia maya akan mempengaruhi daya pikir anak terhadap sesuatu di luar hal tersebut, ia juga akan merasa asing dengan lingkungan sekitar karena kurangnya interaksi sosial.

Interaksi sosial merupakan suatu hubungan antara dua responden atau lebih individu, dimana kelakuan individu mempengaruhi, mengubah atau mempengaruhi individu lain atau sebaliknya. Jadi, ketika perilaku respondentua yang memberikan gadget kepada anaknya tanpa ada pengawasan atau pengontrolan maka akan memberikan pengaruh yang signifikan terhadap perkembangan anaknya.

\section{Hubungan penggunaan Gadget dengan Perkembangan Personal Sosial Anak Usia 3-5 tahun}

Dari hasil analisis hubungan antara bermain gadget dengan perkembangan personal sosial anak usia 3-5 tahun didapatkan bahwa anak yang mengalami keterlambatan (suspect) sebanyak 4 responden anak (11,5\%) dengan intensitas penggunaan gadget > $3 \mathrm{kali} / \mathrm{hari}$ dan durasi penggunaan gadget sedang sebanyak 15 responden anak $(93,8 \%)$.

Hasil uji Chi Square menunjukkan bahwa untuk intensitas penggunaan gadget $(\mathrm{p}=0,041 \alpha$ $=0,05)$ dan untuk durasi penggunaan gadget $(\mathrm{p}$ $=0,032 \alpha=0,05)$ maka dapat disimpulkan bahwa ada hubungan antara bermain gadget dengan perkembangan personal sosial anak usia 3-5 tahun.

Menurut Ferliana [12], anak usia dibawah 5 tahun, boleh-boleh saja diberi gadget. Tapi harus diperhatikan durasi pemakaiannya, misalnya, boleh bermain tapi hanya setengah jam dan hanya pada saat senggang, kenalkan gadget seminggu sekali, misalnya hari sabtu atau minggu. Anak yang kecanduan dengan bermain gadget relatif menjadi pendiam, sehingga anak lebih cenderung pasif dan tidak bisa berprilaku dan berinteraksi sosial secara penuh.

Menurut para pakar pendidikan "Sebaiknya seresponden anak dikenalkan pada fungsi dan cara menggunakan gadget saat berusia enam tahun. Karena di usia tersebut perkembangan otak anak meningkat hingga 95\% dari otak responden dewasa. Sebab, jika mengenalkan gadget di bawah usia enam tahun, anak lebih 
banyak untuk bermain karena anak tertarik dengan visual (gambar) dan suara yang beragam yang terdapat pada gadget".

Tria Puspita Sari dan Ami Asma Mitsalia [10] menyatakan, ketika anak bermain gadget, disamping memberikan dampak positif dan negatif, ternyata hasil penelitian mereka meyebutkan bahwa gadget lebih cenderung memberikan dampak positif daripada dampak negatif. Penelitian mereka menyebutkan bahwa pengaruh penggunaan gadget terhadap personal soaial anak usia pra sekolah di TKIT Al Mukmin cenderung ke arah yang positif yaitu sebanyak $71 \%$. Hal ini disebabkan karena dari gadget anak dapat mengikuti pembelajaran seperti menghafal al qur"an, mengetahui kosakata bahasa inggris, anak juga merasa terbantu dalam membaca ataupun menghafal, gadget juga dapat dijadikan sarana hiburan bagi anak, serta kecerdasan anak terasah saat ia dapat menyelesaikan suatu tahapan game yang lebih tinggi dari sebelumnya. Selain dampak positif yang ditimbulkan gadget, sebanyak 29\% dari responden menyatakan gadget juga memiliki dampak negative bagi anak-anak mereka, seperti halnya anak cenderung pendiam di depan responden yang tidak dikenal, anak lebih senang memainkan gadgetnya daripada bermain dengan temannya, anak terkadang menirukan adegan kekerasan yang ada di game, anak bersikap acuh bila sudah di depan gadgetnya.

Dari hasil penelitian yang dilakukan penulis ini, dapat dilihat pula bahwa anak yang mengalami keterlambatan suspect sebanyak 4 responden anak, hal ini dikarenakan perkembangan personal sosial pada anak dipengaruhi oleh banyak faktor, tidak hanya dari stimulasi bermain gadgetnya saja. Perkembangan personal sosial anak sangat tergantung pada individu anak, peran responden tua, serta lingkungan yang ada disekitar anak. Selain pengalaman yang dimiliki, faktor lain yang mempengaruhi seseresponden dalam menentukan cara mendidik anak adalah pendidikan terakhir. Pendidikan akhir responden tua akan mempengaruhi bagaimana cara seseresponden dalam memberikan bimbingan dan pengajaran pada anak.

Tidak dapat dipungkiri bahwa di era modern ini semua serba digital, semua dipermudah dengan teknologi bahkan barang elektronik seperti gadget dalam hal ini berbentuk tablet ataupun hadnphone hampir semua responden memilikinya dan tidak hanya dipakai untuk kalangan responden dewasa saja tetapi anak-anakpun sudah bisa mengoperasikan gadget. Untuk itu, para respondentua harus mampu mengintrol dan mengawasi anakanaknya dalam memainkan gadget. Dalam penelitian ini, peneliti menemukan kasus bahwa para responden tua kurang dalam hal mengontrol dan mengawasi anak-anaknya dalam bermain gadget, hal ini dikarenakan karena beberapa faktor seperti, responden tua yang sibuk bekerja sehingga waktu yang untuk anak menjadi berkurang, responden tua beranggapan dengan anaknya bermain gadget anaknya menajdi anteng sehingga merkea bisa mengerjakan pekerjaan rumah, bahkan ada beberapa responden tua yang memberikan anaknya bermain gadget agar anaknya tidak main keluyuran di luar rumah.

\section{KESIMPULAN}

Berdasarkan hasil penelitian dapat disimpulkan bahwa ada sebagian anak bermain gadget dengan intensitas penggunaan gadget $>3$ kali/hari dengan durasi sedang 40-60 menit dan beberapa anak usia 3-5 tahun mengalami suspect keterlambatan perkembangan personal sosial yaitu11,8\%. Analisis lanjut menunjukkan terdapat hubungan antara bermain gadget dengan perkembangan personal sosial anak usia 3-5 tahun di TK Cendikia Lingsar, dengan intensitas $p$ value 0,041 dan durasi $p$ value 0,032 .

\section{DAFTAR PUSTAKA}

[1] Adriana, D. (2013). Tumbuh Kembang \& Terapi Bermain pada Anak. Jakarta: Salemba Medika.. 
[2] John W. Santrock. (2007). Perkembangan Anak. Jilid 1 Edisi kesebelas. Jakarta: Erlangga.

[3] IDAI. (2013). Penelitian Keterlambatan Perkembangan. Jakarta: EGC.

[4] Widiastuti, D. (2008). Panduan Perkembangan Anak. Jakarta: Puspa Swara.

[5] Susanto, Ahmad. (2011). Perkembangan Anak Usia Dini Pengantar dalam Berbagai Aspek. Jakarta: Kencana.

[6] Novitasari W \& Khotimah N.Dampak Penggunaan Gadget Terhadap Interaksi Sosial Anak. JPAUD Teratai. 2016;5(3);182-6.

[7] Prabowo, Agung. (2016). Pengaruh Gadget Terhadap Anak Dalam Interaksi Keluarga Muslim Perumahan Winong Kota Gede
Yogyakarta. Jurnal Universitas Islam Negeri Sunan Kali Jaga Yogyakarta

[8] Handrianto. (2013). Dampak Positif dan Negatif Penggunaan Gadget Bagi Anak. Jakarta: Bumi Askara.

[9] Hartanto, H., (2009). Keluarga Berencana dan Kontrasepsi. Jakarta: Pustaka Sinar Harapan.

[10] Sari, P dan Mitsalia A.A. (2016). Pengaruh Penggunaan Gadget Terhadap Persenoal Sosial Anak Usia Prasekolah. Jurnal Profesi: 13 (2) 72-77

[11] Friedman. (2010). Faktor-Faktor Pengaruh Gadget Terhadap Kecerdasan Motorik. Institut Teknologi Sepuluh.

[12] Ferliana, Jovita Maria. (2016). Anak dan Gadget Yang Penting Aturan Main. Jakarta: EGC. 